\title{
St) Scnat
}

\section{Chemistry Travel Award by SCNAT and SCS}

\section{Caroline Reymond ${ }^{\star}$}

${ }^{*}$ Correspondence: C. Reymond, E-mail: chemistry@scnat.ch; Swiss Academy of Sciences (SCNAT), Platform Chemistry, Laupenstrasse 7, CH-3001 Bern

The Platform Chemistry of the Swiss Academy of Sciences (SCNAT) together with the Swiss Chemical Society (SCS) announces the «2020 Chemistry Travel Award». This program supports excellent $\mathrm{PhD}$ students in chemical sciences by sponsoring them to participate in an international conference. Students from all fields of chemistry and from any Swiss institution were invited to participate. The selection committee is set up with four chemists working in diverse fields of chemistry: Prof. Dr. Christian Bochet (SCS, University of Fribourg), Prof. Dr. Catherine E. Housecroft (SCNAT, University of Basel), Dr. Marc Suter (SCS, Eawag), and Prof. Dr. Shana Sturla (SCNAT, ETH Zürich). They each reviewed and rated all of the applications (except their own students'), based primarily on the submitted conference abstract and the scientific achievements.

On behalf of SCNAT and SCS we hereby congratulate this year's winners and wish them a very successful conference participation.

We proudly present the winners of the «2020 Chemistry Travel Award»:

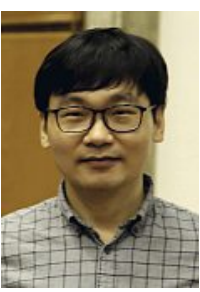

\section{Dalu CHANG}

Group: Prof. Nicolas Winssinger

Conference: EMBO Chemical Biology 2020

Contribution: Luciferase-Induced

Photouncaging: Bioluminolysis

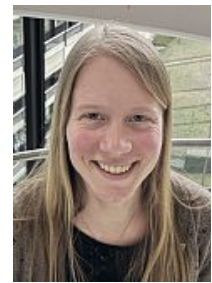

Faustine d'ORCHYMONT

Group: Prof. Jason Holland

Conference: Pacifichem 2020

Contribution: Supramolecular

radiopharmaceuticals for multi-modality

imaging of cancer

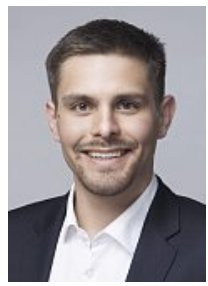

Romain J.-C. DUBEY

Group: Prof. Maksym V. Kovalenko

Conference: 2020 MRS Fall Meeting

Contribution: Silicon Oxycarbide as a Host

Matrix of Choice to Stabilize Li-Ion Storage

in Nanosized Alloying Elements

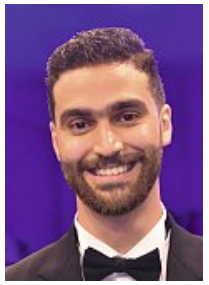

Ahmed ELABD

Group: Prof. Ali Coskun

Conference: PRiME 2020

Contribution: Covalent Triazine Frameworks Incorporating Charged Polypyrrole Channels for High Performance Lithium-Sulfur Batteries

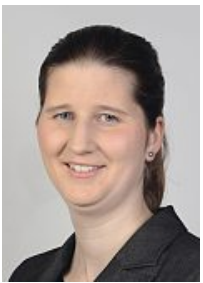

\section{Michelle FREI}

Group: Prof. Kai Johnsson

Conference: MAF2020 Methods and

Applications in Fluorescence

Contribution: Increasing fluorophore

brightness through self-labeling protein tags

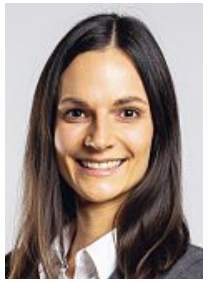

Susanne GEISEN

Group: Prof. Shana Sturla

Conference: ACS Fall 2020 National Meeting

Contribution: Chemical mechanism of O6carboxymethyldeoxyguanine formation from azaserine and abundance in cells

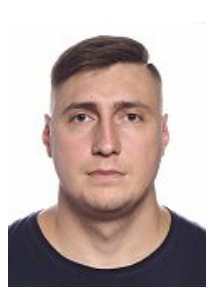

Vladimir GORBACHEV

Group: Prof. Peter Chen

Conference: Gordon Research Conference:

"Gaseous Ions: Structures, Energetics and

Reactions"

Contribution: Cryogenic ion vibrational predissociation (CIVP) spectroscopy of a gas-phase molecular torsion balance to probe London dispersion forces in large molecules

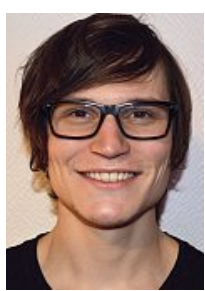

\section{Yannick GUNTERN}

Group: Prof. Raffaella Buonsanti Conference: ACS Fall 2020 National Meeting Contribution: Synthetic route for colloidal nanocrystal/covalent organic framework hybrids

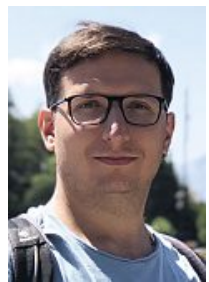

Ilia KOCHETYGOV

Group: Prof. Wendy Queen

Conference: Nanomaterials for Applications in Energy Technology

Contribution: Dimensionality control and rational design of novel nanoporous metalorganic frameworks 


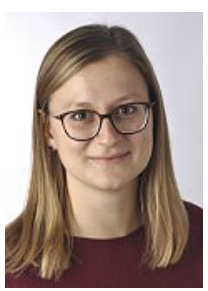

Miriam LINSENMEIER

Group: Prof. Paolo Arosio

Conference: Cell Symposia: Biological Assemblies: Phase Transitions and More Contribution: Droplet-based microfluidic platforms to investigate the kinetics and thermodynamics of phase transitions

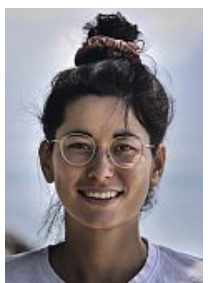

\section{Jade NGUYEN}

Group: Prof. Pablo Rivera-Fuentes

Conference: Pacifichem 2020

Contribution: Disruption of Redox

Homeostasis by Enzymatic Activation of a Triakylphosphine Probe in Mitochondria

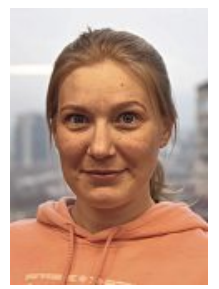

Margarita REKHTINA

Group: Prof. Christoph Müller

Conference: 2020 MRS Fall Meeting and

Exhibit

Contribution: Elucidating the factors

governing the cyclic performance of $\mathrm{MgO}$ -

based sorbents of $\mathrm{CO}_{2}$ using time-resolved in situ XRD/PDF techniques

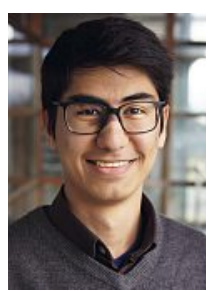

\section{Abdusalom SULEYMANOV}

Group: Prof. Kay Severin

Conference: Pacifichem 2020

Contribution: Synthesis of Tetraarylethene Luminogens by C-H Vinylation of Arenes with Triazenes

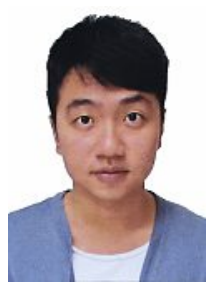

\section{Jin Fay TAN}

Group: Prof. Nicolai Cramer

Conference Pacifichem 2020

Contribution: Highly Divergent Access to

Densely Substituted Arenes, Pyridines and Pyridones via Transition Metal-Catalyzed

Transformations of Alkynyl Triazenes

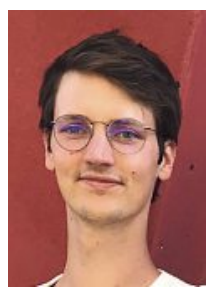

Zacharias THIEL

Group: Prof. Pablo Rivera-Fuentes

Conference: Pacifichem 2020

Contribution: Single-Molecule Imaging of Active Enzymes in Live Cells Using PhotoCrosslinking Probes

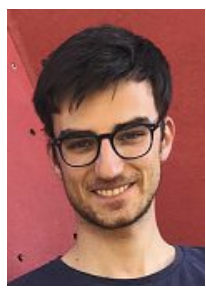

Matthias TINZL

Group: Prof. Donald Hilvert

Conference: Girona Seminar 2020

Contribution: Enhancing catalysis of iron heme metalloproteins using non-canonical amino acids

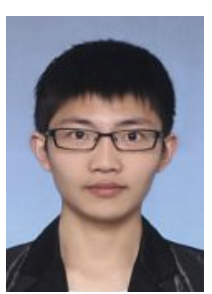

\section{Ming-Ming WANG}

Group: Prof. Jerome WASER

Conference: ICOS 2020: XXIII International

Conference on Organic Synthesis

Contribution: Oxidative Ring-opening

Fluorination of Cyclopropylamides

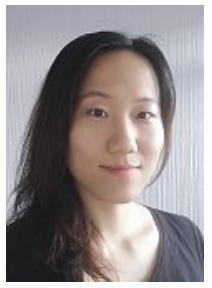

\section{Yanan WANG}

Group: Prof. Thomas Buergi

Conference: The 20th incarnation of the

International Symposium on Small Particles

\& Inorganic Clusters

Contribution: Deracemization of Au38

Clusters: Breaking the Equal Status and

Dynamic Inversion of Enantiomers

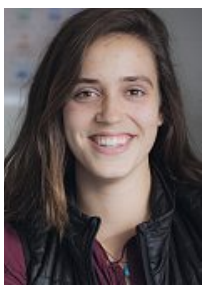

\section{Rebekah WELLS}

Group: Prof. Kevin Sivula

Conference: PRiME 2020

Contribution: The roll-to-roll deposition of 2D nanoflake films of semiconducting TMDs for large area solar-to-chemical energy conversion

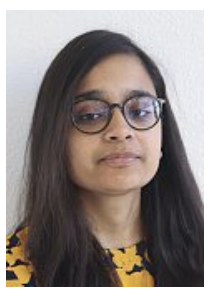

\section{Prerna YADAV}

Group: Prof. Felix Zelder Conference: EUROBIC 15

Contribution: Disassembly Approach for the Selective and Sensitive Detection of Pyrophosphate

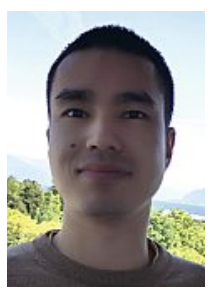

\section{Xiangli YI}

Group: Prof. Xile Hu

Conference: ICOS 2020: XXIII International

Conference on Organic Synthesis

Contribution: $\mathrm{Cu}$-involved electrocatalysis and photocatalysis for the synthesis of allyamine derivatives from unactivated alkenes

Due to the pandemic situation taking place this year worldwide, some conferences are being cancelled, postponed or switched into a virtual event. The attendance of the winners to the conferences may change from the present list.

Additional information about the Platform Chemistry and its activities may be found at chemistry.scnat.ch

Do not miss the «2021 Chemistry Travel Award», which will be announced early in 2021 on chemistry.scnat.ch/travel_award and in Chimia. 